\title{
DESCRIPTION OF THE DEVELOPMENTAL STAGES OF THE MITE PREDATOR, OLIGOTA OVIFORMIS CASEY, WITH NOTES ON THE OSMETERIUM AND ITS GLANDS (COLEOPTERA: STAPHYLINIDAE)
}

\author{
By Ian Moore, E. F. Legner and M. E. Badgley ${ }^{1}$ \\ Department of Entomology \\ Division of Biological Control \\ University of California, Riverside 92502
}

Oligota oviformis was described by Casey in 1893 . Quayle (I912, I9I3) called attention to the fact that both larvae and adults were predaceous on spider mites and consequently beneficial in orchards where mites were a pest. Quayle partially outlined the life history of $O$. oviformis but was unable to induce pupation. Ewing (1914) and Essig ( 1926) reviewed Quayle's work. Badgley and Fleschner ( 1956) were able to induce pupation by providing a floor of sand in which pupation took place. However, little detailed description of the early stages was provided. A brief account of the osmeterium of the larva and its protective opercula was given by Badgley and Fleschner. The osmeterium is of particular interest as its occurrence appears to be widespread among the Aleocharinae, although it has been misinterpreted (Badgley and Fleschner, 1956).

\section{Larva of Oligota oviformis Casey}

Length 2.I mm (mature larva). Body elongate, subcylindrical, tapered at each end; integuments soft, not chitinized, without distinct sclerites; pale testaceous with the opercula of the osmeterium piceous, darkest along the posterior margin of eighth tergite, osmeterium bright orange. Head oval, about as wide as long, with a single ocellus on each side behind the antennal fossae. Epicranial suture absent. Antennal fossae located at sides of head outside the bases of the mandibles. Antennae three-segmented; first segment about as long as wide; second segment narrower than first, a little more than twice as long as wide, with two long setae near the middle and a modified "acorn seta" without obvious articulation at base; third segment about half as wide as second and a little more than twice as wide, with two long setae at apical third and a shorter

\footnotetext{
1Staff Research Associate, Professor of Biological Control, and Staff Research Associate, respectively.

Manuscript received by the editor June 16, 1975
} 


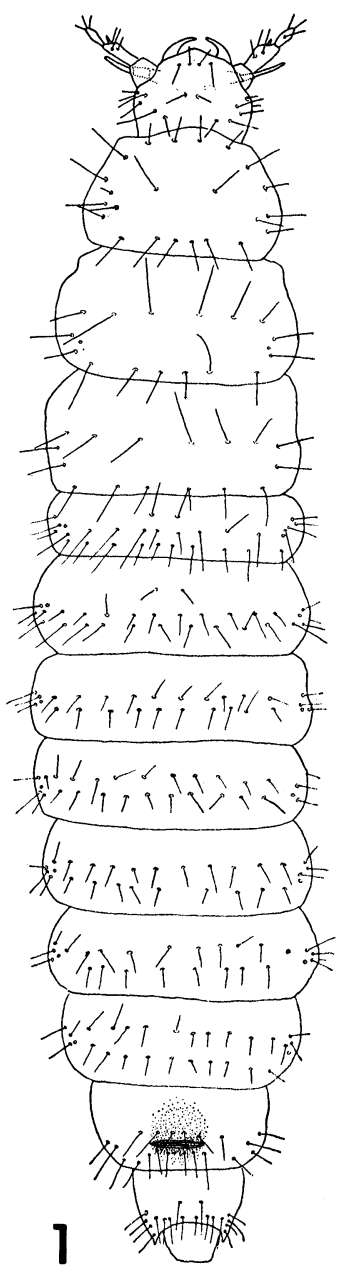

Figure 1. Oligota oviformis. Larva, dorsal aspect. 

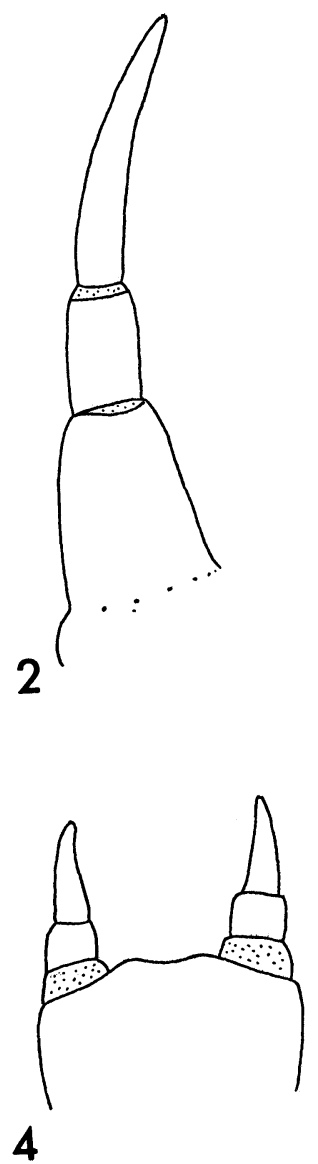
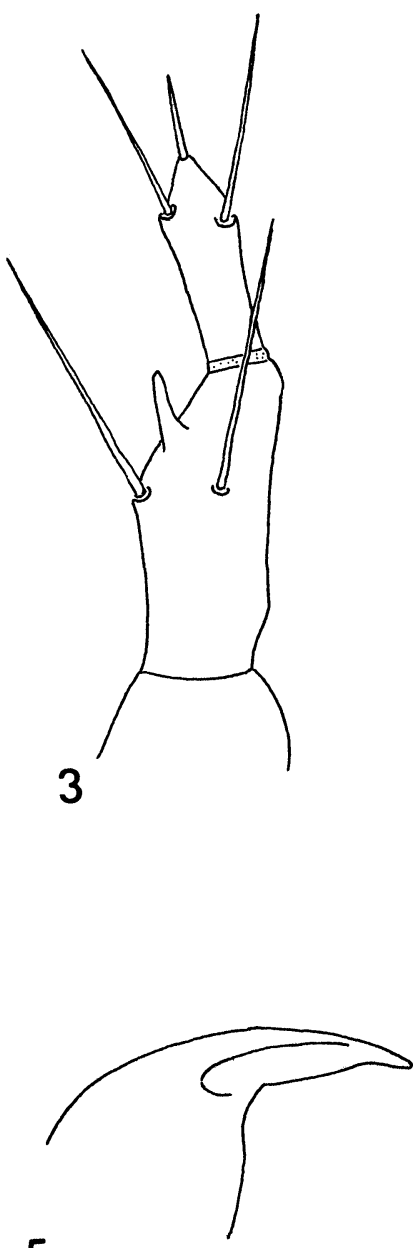

5

Figures 2-5. Oligota oviformis, larva. Fig. 2, maxillary palpus. Fig. 3, antenna. Fig. 4, labium. Fig. 5, right mandible. 
stout seta at pointed apex. Mandibles simple, stout at base, narrowed in apical two-fifths, arcuate externally, pointed at apex. Maxillary palpus three-segmented; first segment somewhat longer than wide, narrowed to apex; second segment a little narrower than apex of first, almost twice as long as wide, nearly paraliel sided; third segment narrower at base than apex of second, almost four times as long as wide, gently arcuate, gradually pointed to apex. Labial palpus two-segmented; first segment about as long as wide; second segment narrower than first, a little more than twice as long as wide, slightly arcuate, gradually narrowed and pointed to apex. Pronotum wider than head, narrowed in front, wider than long, with a row of four setae along front margin, a pair of setae on disc, four setae along lateral margin, two setae in sub-lateral series and six setae along posterior margin. Mesonotum about as long and a little wider than pronotum, with no setae at anterior margin, six transversely arranged on disc, two in the lateral series and six in the basal series. Metanotum about the same size and shape as mesonotum with chaetotaxy the same. Abdomen. First abdominal segment about as wide as metanotum and half as long as metanotum; without setae at anterior margin; with two transverse rows of discal setae, the first of two setae and the second of ten setae, with ten setae along the posterior margin and three or four irregularly placed setae at each side. Second abdominal segment about as wide as first and almost as long as metanotum; with setae arranged almost as on first segment except the setae are moved forward so that there are two discal series of eight setae each and none along the posterior margin. Third through seventh segments very similar in all respects to second except the seventh is narrower than the sixth and the two anterior setae are lacking on all but the first two segments. Eighth segment narrower than seventh but about as long; with two dark conjointly oval opercula in the middle near the posterior margin, divided longitudinally so that the anterior operculum is the largest; with chaetotaxy as on seventh segment. Ninth segment narrower than eighth, about as long as wide; with two discal setae and about eight or ten setae along the posterior margin; the outer apical angle produced on each side in a pointed fleshy urogomphus which apparently has no basal articulation and is unsegmented. Pseudopod produced between and beyond urogompi. Spiracles present at the outer margins of the mesothorax and the first seven abdominal segments with much the appearance of empty hair follicles.

Three specimens, Carlsbad, San Diego County, California, I7 September 1970, on avocado leaves, Horace G. Johnson collector. 


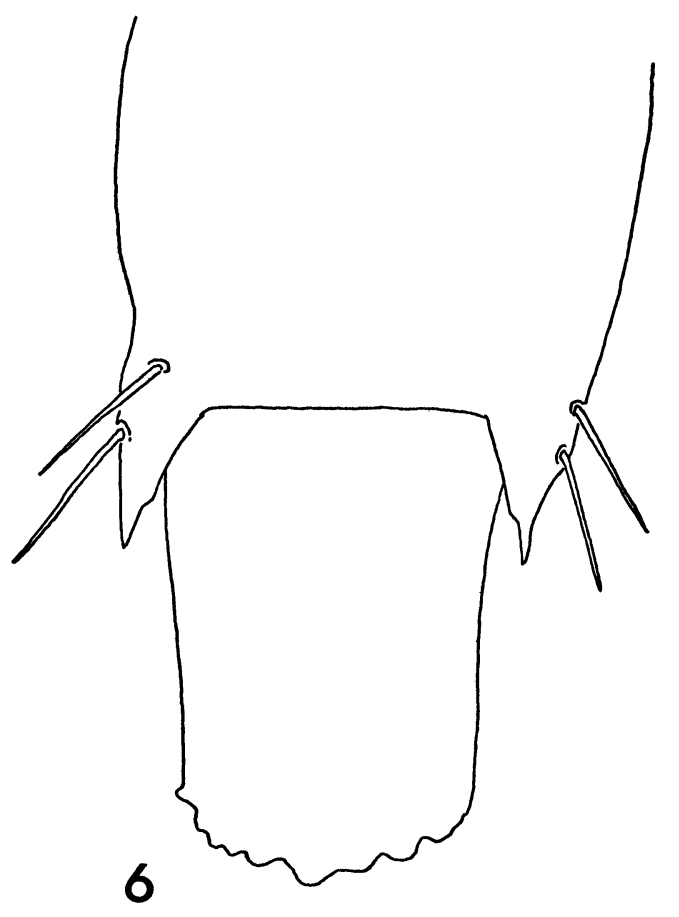

Figure 6. Oligota oviformis, larva. Pseudopod and urogomphi.

The larva of Oligota oviformis is similar to that of $O$. Aavicornis Boisduval and Lacordaire as described and illustrated by Paulian (I94I). The two species differ in that in O. oviformis the "acorn seta" of the second antennomere is almost as long as the third segment and has no distinct articulation at its base whereas Paulian's illustration of $O$. Alavicornis shows two very small "acorn setae" with distinct articulations at the base. In $O$. oviformis the urogomphus is an extension of the eighth segment without articulation or segmentation. In $O$. favicornis it is distinctly two-segmented.

Pupation takes place in a cocoon in which the pupa is quite loose. The cocoon is formed of sheets of silk to which grains of sand adhere. In one instance the cocoon was formed in part of several sheets of silk extending like short walls perpendicular to the axis of the pupa. 


\section{Pupa of Oligota oviformis Casey}

Pupa exarate, pale yellow, ovid, about one and one-half times as long as wide, not chitinized in any part, without tubercles. Head ventrally reflexed so that none of it is visible from above; with a single dark eye spot on each side; with two long setae above each eye spot. Pronotum hemispherical, wider than long; with a row of setae along the anterior margin, the two outer and the middle setae distinctly longer than the other six. Elytra each about as long as wide, about as long as pronotum, with outer apical angles broadly rounded and inner apical angles narrowly rounded. Wings as seen from below almost twice as long as elytra. Abdomen apparently eight-segmented as viewed along the side margins of the paratergites; segmentation of tergites and sternites indistinct; segments two through seven each with a short seta on each side of side margin; eighth segment with a diaphanous bidentate process at apex each tooth of which is swollen at tip.

Three specimens reared from larvae collected at Riverside, Riverside County, California, 22 April 1975, lemon leaves, Ian Moore collector.

This is the first description of a pupa of a member of this genus.
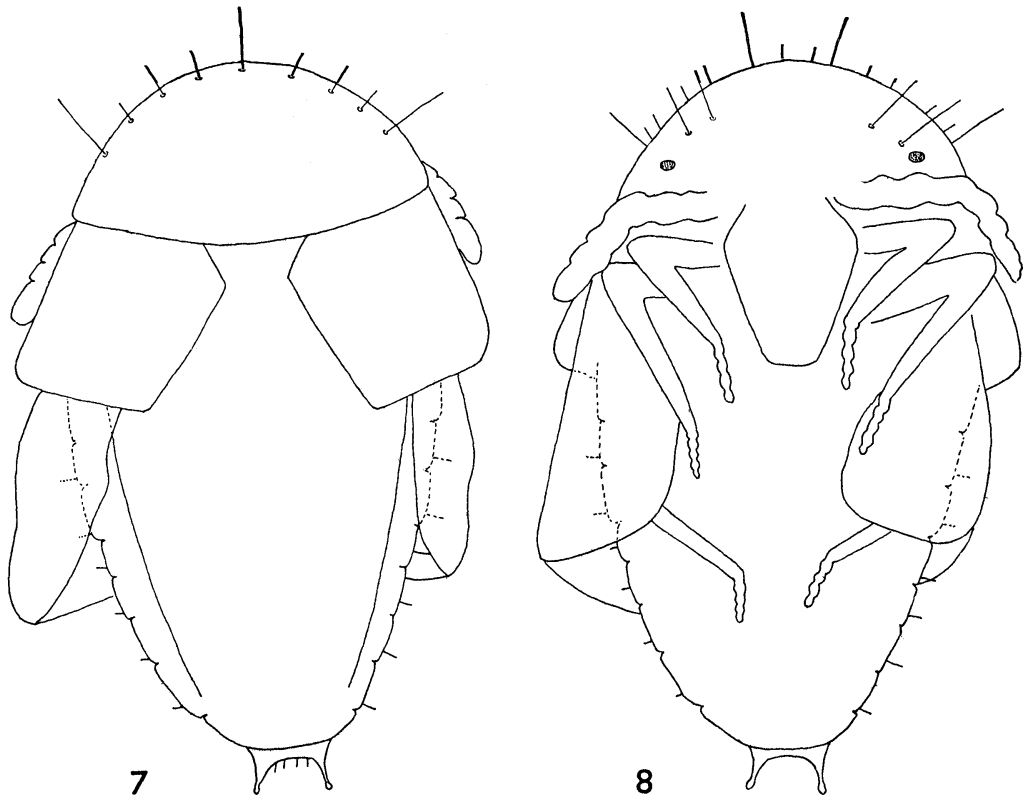

Figures 7 and 8. Oligota oviformis, pupa. Fig. 7, dorsal aspect. Fig. 8, ventral aspect. 
The Osmeterium

The eighth abdominal tergite of many larvae of the subfamily Aleocharinae bears in its center near the posterior margin a dark tumid area of distinctive texture which has usually been called a gland. Paulian (194I) referred to it as a silk gland. Badgley and Fleschner (1956) disclosed that in O. oviformis it is a cover for an osmeterium. They stated, "This black spot consists of two heavily pigmented, chitinized plates, with a transverse slit between them. The plates appear to act as a protection for an inner bladderlike organ called an osmeterium. It apparently acts as a protective device, quite possibly giving off an offensive odor, as does the osmeterium of certain lepidopterous larvae." When a larva was prodded with a camel's hair brush the two opercula parted and the bright orange osmeterium protruded from one to two seconds. The osmeterium appeared to be about as long as wide. According to Paulian (194I) the following genera possess this structure: Alianta, Antarctophytosus (=Halmaeusa), Bolitochara, Gyrophaena, Lomechusa, Microglotta, Oligota, Phloeopora and Thectura. Moore (1956) confirmed its presence in Diaulota, Liparocephalus and

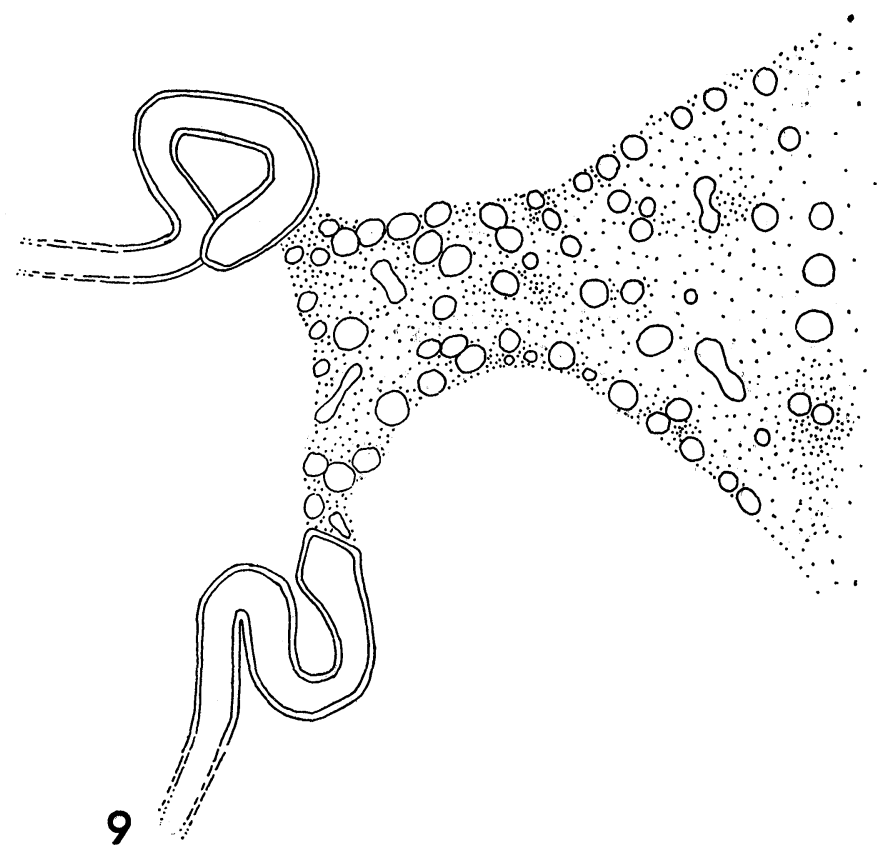

Figure 9. Oligota oviformis. Larva. left pair of osmeterial glands. 
Phytosus. Paulian (194I) reported it absent in Aleochara, Atheta and Cyphea.

\section{Osmeterial Glands}

Through the transparent integuments of the larvae of $O$. oviformis there are visible on each side of the area of the osmeterium a pair of tubular coiled structures which appear to be connected to the osmeterium by convoluted material. These would seem to be glands so it may be reasonable to call them osmeterial glands. If the osmeterium gives off an offensive odor these could be its source.

\section{Acknowledgements}

We are indebted to H. G. Johnson, J. A. McMurtry, E. R. Oatman, R. E. Orth and G. R. Platner all of the Division of Biological Control of the University of California at Riverside for assistance in the field and in the laboratory in connection with this study.

\section{Literature Cited}

Badgley, M. E. and C. A. Fleschner.

1956. Biology of Oligota oviformis Casey (Coleoptera: Staphylinidae). Ann. Ent. Soc. America. 49: 501-502.

\section{CASEY, T. L.}

1893. Coleopterological Notices V. Ann. New York Acad. Sci. 8: 281-606.

Essig, E. O.

1926. Insects of Western North America. The Macmillan Co., New York, $1035 \mathrm{p}$.

EwING, H. E.

1914. The common red spider or spider mite. Bull. Oregon Agric. Coll. $121: 1-94$.

McMurtry, J. A., C. B. Huffaker and M. Van Der Vrie.

1970. Ecology of tetranychid mites and their natural enemies: A review. I. Tetranychid enemies: Their biological characters and the impact of spray practices. Hilgardia 40: 331-390.

MOORE, IAN.

1956. Notes on intertidal Coleoptera with descriptions of the early stages (Carabidae, Staphylinidae, Malachiidae). Trans. San Diego Soc. Nat. Hist. 12: 207-230, illus.

Paulian, Renaud.

1941. Les premier états des Staphylinoidea. Étude de morphologie comparée. Mém. Mus. Hist. Nat. Paris, N. Ser., 15: 1-361, illus. QUAYLE, H. J.

1912. Red spiders and mites of citrus trees. Bull. Univ. Calif. Agr. Exp. Sta. 234: 483-530.

1913. Some natural enemies of spiders and mites. Jour. Econ. Ent. 6: 85-88. 

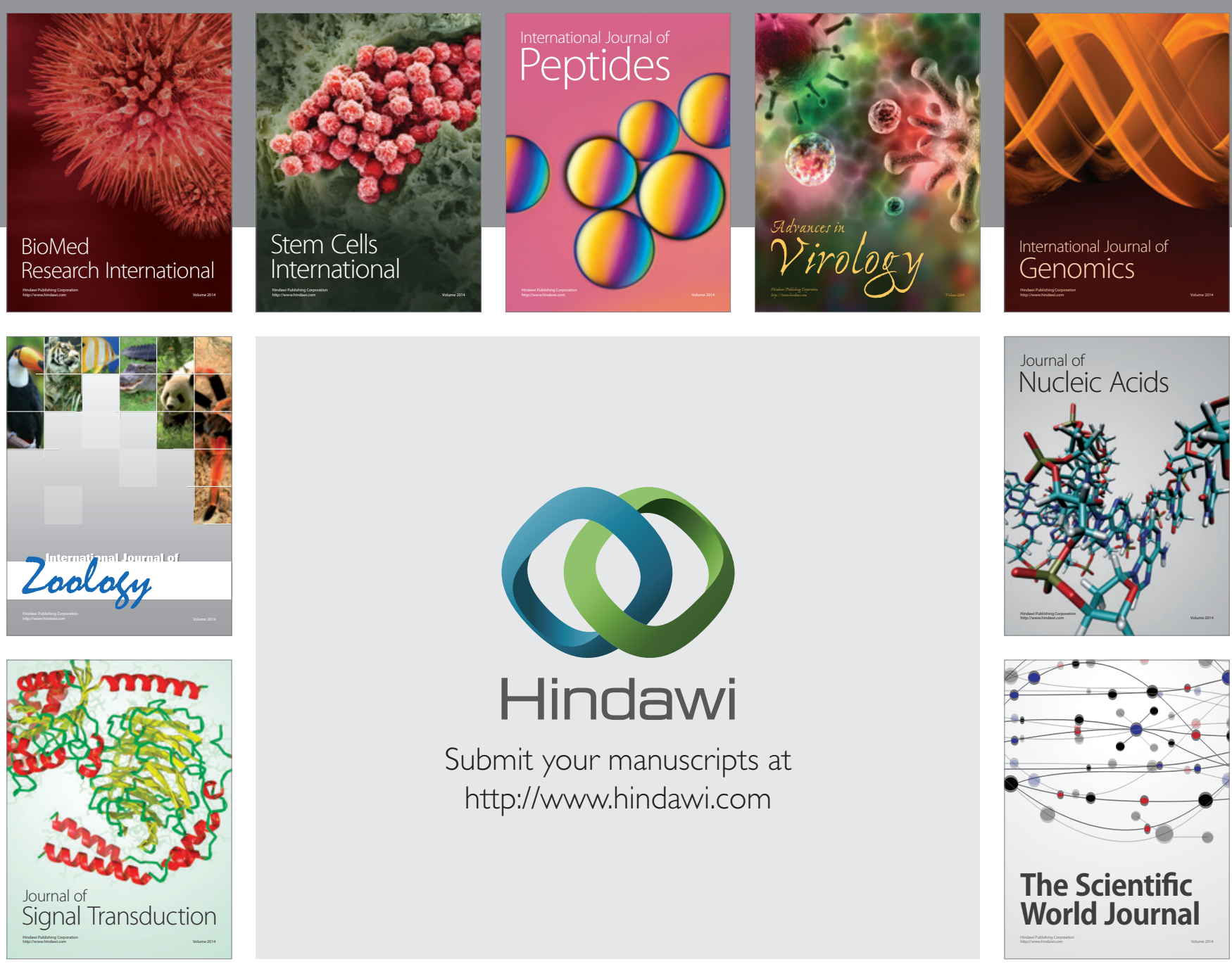

Submit your manuscripts at

http://www.hindawi.com
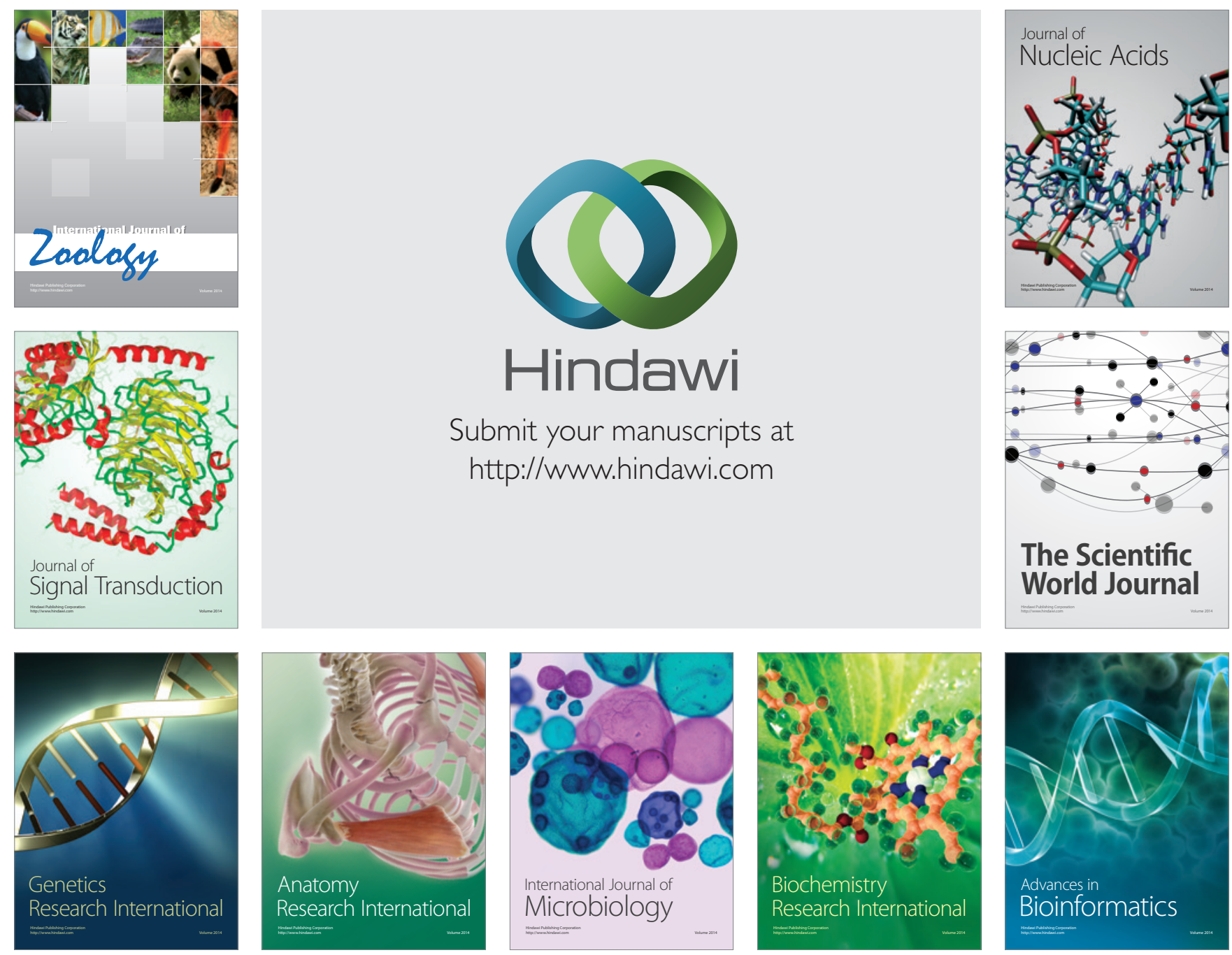

The Scientific World Journal
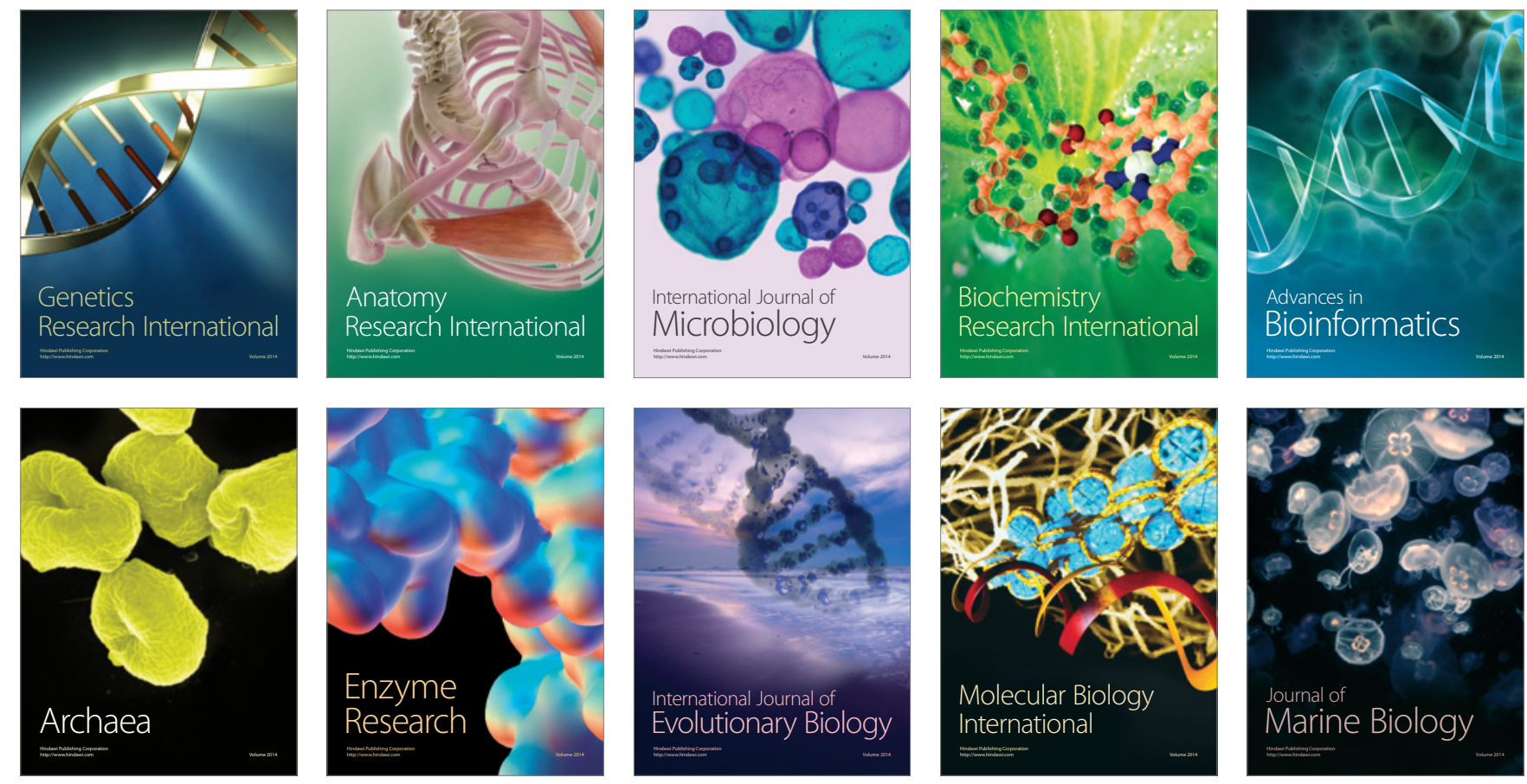